\section{Organic Gardening and Ecosystem Alteration}

\section{Miklos Faust}

Additional index words. soil-root zone, soil ecology, plant-pest interactions

A t the simplest level, the word "organic" refers to a certain method of growing food. It can be defined negatively: organically grown produce is that which is grown without the use of chemical fertilizers and pesticides. More positively, as the English estate owner Friend Sykes (1888-1965) asserted: "Organic Farming...is another name.. for Humus Farming. Organic methods are not, therefore, a matter of avoiding the use of artificials; they require that the cultivator should encourage the fertility which lies, actually or potentially, in the soil itself, and should regard the soil not as inert matter but as a living organism" (quoted by Conford, 1988). This reasoning can be extended from the soil to the plants themselves. Organic methods do not merely avoid pesticides but encourage the productivity potential of plants by regarding the plant-pest interaction not as an exclusive "either/or" process but as an ecological interplay of competitive organisms. Problems arise when a balanced ecosystem is altered, either because the plants were moved for economic reasons or the pests were moved by unnatural dislocation, causing the plant-pest interplay to becomeoverwhelmingly in favor of the pests. Consequently, we must consider the soil-root-zone and the plant-pest ecosystems as two separate systems, both being susceptible to ecological adjustments.

\section{Soil-root-zone ecosystem}

The soil-root-zone ecosystem, discussed earlier in this Workshop, can be summarized quickly. Altering soil ecology, by means of improving humus in the soil, was advocated by R.H. Elliot in 1898 in his "Clifton Park" method (Conford, 1988) and by Sir Albert Howard in the Indore process (Conford, 1988). Elliot (1837-1914) was concerned about the application of artificial fertil-

Fruit Laboratory Beltsville Agricultural Research Center, Agricultural Research Service, Beltsville, MD 20705 . izers. He developed his system in Roxburgshire and wrote that the soil fertility could be improved without artificial fertilizers by relying on deeprooted plants and turf and root residues. Howard (1873-1947) the developer of the Indore process, worked from 1905 to 1931 in India and applied scientific knowledge to ancient techniques of composting to maintain soil fertility.

Soil fertility was a concern long before Howard's work. The Chinese have used night soil to improve soil fertility since ancient times. Entz (1854) recognized that replanting of grapes was not satisfactory unless the soil $\mathrm{N}$ status was improved. He advocated heavy manuring of the soil, or better yet, planting of alfalfa for 4 to 5 years until the productivity of the soil noticeably improved.

Nagyvathy (1822) was concerned with the quality of the soil itself and with the modifications that were needed to make it productive. He stated that a "balanced soil" (mixture of sand and clay) is the best for agricultural production, and that, in most cases, nature produced such soils, mixing clay with sand and sand with clay. Where nature did not comply, he said, it was the farmers responsibility, and he should cover the land with good soil during the fall. He recommended using mud from the bottom of dried lakes for improving soil fertility. Nagyvathy stated that land improved with the right kind of soil would be productive longer than after any manuring treatment.

Of course, all these ecological adjustments were used before Liebig introduced artificial fertilizers. Synthetic fertilizers became increasingly important during the second part of the 19th century and throughout the 20th, until now it is impossible to design anagricultural land managementsystem without them. What we can learn from the early period of agricultural farming is that we should consider the ecology of the system. For example, if soil leaches easily, fertilizers should be applied in small doses more often to maintain soil fertility.

In addition to fertility, soil structure needs to be maintained for maximum soil-root interactions. Nagyvathy, a county judge in Hungary, noticed that farmers who used four oxen to pull their plows plowed more deeply and had plenty of bread, compared with those using only two oxen, whose plowing was shallower and who had less to eat (Nagyvathy, 1822). These observations are directly related to the depth of the root zone, widely recognized as a necessity today.

There are some novel systems where adjustment of the ecosystem has greatly increased soil productivity. The Tisza River in Hungary used to flood its tributaries, frequently causing much loss of property and life. During the second part of the 19th century, the river was regulated, and flooding was eliminated. But it soon became obvious that the flood waters had regularly dissolved soil sodium, for after the floods were eliminated, the salinity of the soil became too high for the traditional wheat and corn production of the area. Adjustments were clearly necessary. Thus, in areas where the soil 
could be leveled, rice fields were developed in which artificial, controlled flooding dissolved and washed away the sodium. In areas where the sodium content of the soil was too high or rice could not be planted, the solution was production of chamomile (Matricaria chamomilla), a plant that tolerates high sodium in the soil. Chamomile was used first as a folk medicine and later as a source of raw material for the pharmaceutical industry.

\section{Plant-pest interactions}

Alteration of plant-pest interactions can be cited from the time when this was the most effective means of decreasing pest damage. For comparative purposes, I need to mention that chemicals have been used in agriculture since antiquity (Smith and Secoy, 1975); but effective sprays were developed only near the turn of the 20th century (Smith and Secoy, 1976). "Bouillie Bordelaise," or bordeaux mixture, a mixture of lime and copper sulfate, originated in France in 1885 and was first used in Connecticut in 1893. Lime-sulfur, a mixture of sulfur and lime boiled in water, was first used in California in 1905.

Starting early in the 17th century, colonists made many unsuccessful attempts to establish Vinifera grapes in the eastern United States. Failures were due to lack of resistance of the imported grapes to native diseases and soil pests. It was gradually recognized that the wild native species could contribute resistance to these conditions. Between 1800 and 1850, such cultivars as 'Catawba', 'Isabella', and 'Concord' came to the scene, the grapes and their ecosystem were harmonized, and the hybrids became the foundation of the grape industry in eastern North America (Einset and Pratt, 1975).

Similar problems occurred when grape pests from the New World were introduced to Europe during the 19th century. Phylloxera (Phylloxera vitifoliae) is an insect that lives on the roots of grapes; it is indigenous to the eastern and central United States and was carried to France some time before 1860 (Einset and Pratt, 1975). Hybridization of native American species assumed importance in France when the devastations of phylloxera made it necessary to graft Vinifera grapes on resistant roots. The new rootstocks, developed with North American native grapes that were resistant to phylloxera, altered the relationship between pest and plant and allowed the production of grapes even in the presence of the insect.

During the 17th and 18th centuries, only imported pear cultivars derived from Pyrus communis were grown in North America. The trees were dying from an unknown malady. Then Peter Kieffer (1812-90) a gardener born in Alsace, France, who had immigrated to America in 1834, imported seeds of Sand Pear of China from a Belgian nurseryman. He grew the Sand Pear seedlings in his garden near Philadelphia. There were also some 'Bartlett' trees in his garden, and the two hybridized. One of the chance seedlings was able to cope with the malady (later identified as a bacteria, Erwinia amylovora). This seedling was introduced in 1863 and named 'Kieffer' in 1876 (Hedrick, 1921). Another chance seedling had a similar origin in the Philadelphiaarea, butwhether it was from Kieffer's nursery is not known. It was carried to Georgia about 1850 by Major Le Conte and eventually named 'Le Conte' (Hedrick, 1921). The introduction of $P$. ussuriensis, another Chinese species, to Iowa in 1867 further enlarged the resistance pool against fire blight, a disease that was not even known until 1880 (Burrill, 1880). Sprays were not used against the disease until 1927 (Van der Zwet and Keil, 1979); scientific breeding for fire blight resistance started in 1908 (Brooks et al., 1967).

There were some early attempts to develop resistant vegetables during the 19th century. Chauncey Goodrich, a clergyman of Utica, N.Y., received a small quantity of South American potatoes in 1851 through the American consul in Panama. Using this stock, he was the first breeder to attempt to control late blight (Phytophthora infestans) of potato, and he introduced a cultivar named 'Garnet Chili' (Stevenson and Clark, 1937). This early discovery did not receive attention until potato breeding was undertaken actively by the U.S. Dept. of Agriculture in 1910. Results were evident by the early 1930s and cultivars with virus resistance (latent mosaic virus and mild mosaic), resistance to common scab (Actinomyces scabies), fusarium, and leaf roll were produced by the U.S. Dept. of Agriculture, New York (Cornell) and Minnesota Agricultural Experiment Stations (Stevenson and Clark, 1937).

Yet another example is the tomato. Selection for resistance to fusarium wilt of tomato was started in 1910 by S.H. Essary of the Tennessee Agricultural Experimental Station and by C.W. Edgerton, of the Louisiana station. Two years later, Essary distributed a cultivar that became known as 'Tennessee Red'. In the same year, Edgerton announced his first wilt-resistant tomato, called 'Louisiana Wilt Resistant'. Although 'Louisiana Wilt Resistant proved highly resistant to the disease, it was late and a poor yielder. Edgerton crossed it further and developed new cultivars by 1918. In 1912, J.B.S. Norton of Maryland began selection for wilt resistance; he distributed resistant selections in 1915. The U.S. Dept. of Agriculture started diseaseresistance breeding of tomatoes in 1915, and in 1917 and 1918 introduced 'Norton Columbia' and 'Arlington', which were highly resistant to this disease (Boswell, 1937).

Improvement of beans started about the same time. The first cultivar resistant to common bean mosaic virus (Robust, dry shell bean) was introduced by F.A. Spragg of Michigan in 1913. By 1930 practically all bean introductions later listed by B.L. Wade carried some sort of resistance against anthracnose, bacterial blight, and even bean rust (Wade, 1937).
A different type of ecosystem adjustment was needed in dealing with weeds. Development of English, Dutch, or German land rotation was primarily designed to deal with weedseffectively. The succession of the plants in the rotation was crucial. In one example, from 1793 in Hungary (Nagyvathy, 1822) the planting succession of plots and the reasons for scheduling them in this order was as follows:

\section{Fallow}

Plowed twice to promote maximum weed seed germination.

Wheat

A poorly competing crop, planted in relatively weed-free soil after fallow.

Barley with clover

This is the 2 nd year after fallow, barley is a better-competing crop, clover helps keep weeds down.

Clover

Enriches soil N, effectively crowds out weeds.

Rye or wheat

After the second cut of clover, there is time for only one plowing, but this is enough after clover. Rye is favored because it can be planted later than wheat.

Oat

A relatively high weed-producing crop, but

it precedes fallow, which eliminates weed

In designing this system, the biology of the plants was superbly understood and ecological characters were used to maximize production.

Other systems also were noted for adjusting the ecosystem to eliminate weeds. Nagyvathy (1822) noted that when a field is infested with elder (Sambucus nigra) the best practice is to plant clover in that field. Cutting the clover twice also cuts and consequently weakens the elder; then plowing the field during a dry period completely eliminates the weed (Nagyvathy, 1822). He recommended finding the weakest links in the biology of the weed and exploiting it for the weeds elimination.

\section{Organic agriculture and ecosystem adjustment}

In discussing the "History of Organic Movement," we must ask, what is organic agriculture? The answer lies in understanding and adjusting the production ecosystem for maximum productivity. In the middle of this century, agricultural and horticultural production started to use chemicals in place of ecological adjustments. It appeared that chemicals could overcome certain problems, eliminate pests and weeds, control growth, and replace soil fertility. The use of chemicals started at the same time that science entered into agricultural production. The great increases in productivity (produced by general scientific knowledge) 
were not easy to separate from the effects of chemicals, and to many, perhaps, chemicals created the productivity.

A small group of idealists objected to the use of chemicals, and from this the "organic movement" grew into national and international dimensions. We now know that during the time we used chemicals extensively we neglected to study and adjust the ecosystems of agricultural production. When we began to remedy this problem with endeavors such as modern integrated pest management (IPM), for example, we were merely repeating what had been practiced on a less sophisticated level and with a limited number of crops during the last century. IPM immediately reduced, but did not eliminate, the need for chemicals without reducing productivity. What we must do now is increase our efforts in ecological adjustments of production that will further decrease the need for chemicals. We, probably collectively, can state that chemicals per se are not bad; but they must be environmentally compatible and used in a way that considers the ecology of the system.

\section{Literature Cited}

Boswell, V.R. 1937. Improvement and genetics of tomatoes, peppers and eggplant. Yearbook of agriculture 1937. U.S. Dept. Agr., Govt. Printing Office, Washington, D.C. p.176-206.

Brooks, H.J., T. Van der Zwet, and W. Oitto. 1967 The pear breeding program of the United States Department of Agriculture. Chronica Hort. 7:34-35.

Burrill, T.J. 1880. Anthrax of fruit trees; or the so-called fire blight of pear, and f-wig blight of apple trees. Proc. Amer. Assn. Adv. Sci. 29:583-597.

Conford, P. 1988. The organic tradition. Green Books, Bideford, Devon, U.K. p. 224.

Einset, J. and C. Pratt. 1975 Grapes, p.130-153. In: J. Janick and J. Moore (eds.). Advances in fruit breeding. Purdue Univ. Press, West Lafayette, Ind.

Entz, F. 1854-1959. Kerteszety fuzetek 1 to 15 (Horticultural notes 1 to 15 ; originally published as leaflets). Facsimile ed. MEM Info. Ctr., 1978, Budapest.

Hedrick, U.P. 1921. The pears of New York. J.B. Lyon, Albany, N.Y. p. 635.
Nagyvathy, J. 1822. Magyar practicus termeszto (Hungarian practical grower). Petrocai Tratter Press, Pest, Hungary. p. 295.

Smith, A.E. and D.M. Secoy, 1975. Forerunners of pesticides in classical Greece and Rome. J. Agr. Food Chem. 23:1050-1055.

Smith, A.E. and D.M. Secoy. 1976. A compendium of inorganic substances used in European pest control before 1850. J. Agr. Food Chem. 24:11801186.

Stevenson, F.J. and C.F. C/ark. 1937 Breeding and genetics in potato improvement. Yearbook of agriculture 1937. U.S. Dept. Agr., Govt. Printing Office, Washington, DC. p.405-444.

Van der Zwet, T. and H.L. Keil 1979. Fire blight. A bacterial disease of rosaceous plants. Agr. Hdbk. 510, U.S. Dept. Agr., Washington, DC. p. 200.

Wade, B.L. 1937. Breeding and improvement of peas and beans. Yearbook of agriculture 1937. U.S. Dept. Agr., Govt. Printing Office, Washington, DC. p. 251282.

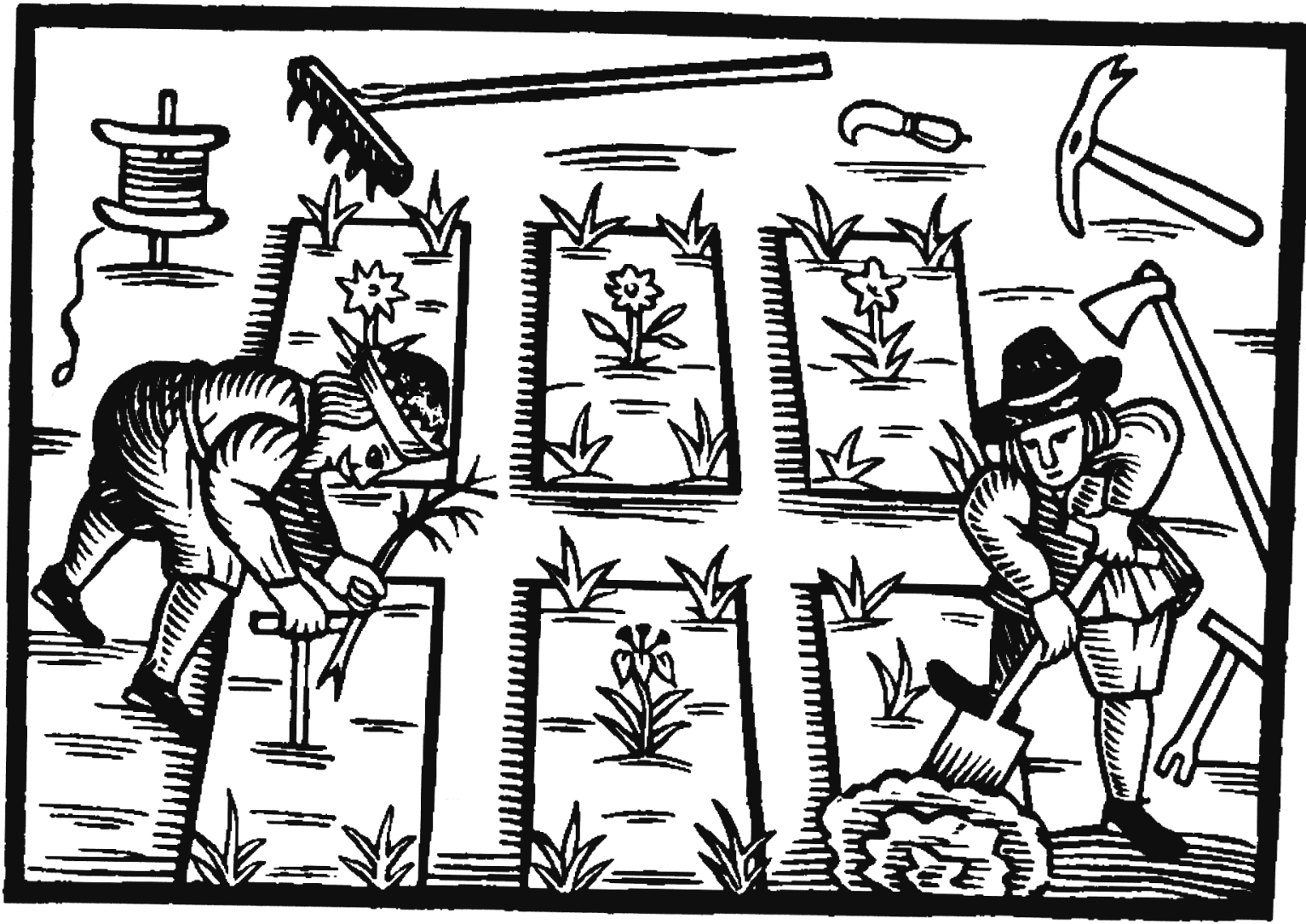

